\title{
Pricing of the commodity market on the example of an integrated model of the economy of the cocoa industry
}

\author{
Antonina Sharkova ${ }^{1, *}$ and Irina Sycheva ${ }^{2}$ \\ ${ }^{1}$ Financial University under the Government of the Russian Federation, 125993, Moscow, \\ Leningradsky, 49, Russia \\ ${ }^{2}$ Head of the Foreign Trade Department, Heritage Trade FZE, Dubai, United Arab Emirates
}

\begin{abstract}
The article describes the peculiarities of pricing of the cocoa industry, the world experience of state management of export supplies of beans that affect international trade in raw materials. The factors influencing the exchange pricing of large volumes of supplies were identified. An integrated price model based on the economic relationships of the cocoa market has been developed.
\end{abstract}

\section{Introduction}

Cocoa has a long history. Its beans are the main ingredients of the chocolate and other industries. More than $50 \%$ of the world's production of this product is accounted for by Ivory Coast and Ghana. An important feature of the market is that $90 \%$ of the world's cocoa production is exclusively accounted for by farmers who seek to maintain their sales capacity, pursuing two main goals - stability of supply, and as a result, export prices and an increase in global demand for beans by improving their quality.

The problems of this industry are expressed in the fact that the price that the farmer sets for his raw materials is the minimum share of the price that the end user pays for chocolate. The formation of an appropriate pricing policy for the normal interaction of the key players in the cocoa market is the main industry task in the conditions of exchange trading in beans.

The purpose of the study is to develop an integrated model of the cocoa economy, which is a correlated system consisting of particular paradigms of raw materials markets and their derivatives, each of which describes the main aspects of the structure of business processes of a single industry, and all together they form a comprehensive view of the pricing of beans and their processed products - butter and powder.

The scientific novelty consists in the fact that for the first time a price model of two derivatives of the same raw material has been created, and the factors influencing it have been described.

The price of cocoa beans for the first time in the last four years increased by $14 \%$ and in February 2020 reached 2,988 US dollars per 1 ton. The record rise in the price of raw

\footnotetext{
* Corresponding author: angela-1309.m@yandex.ru
} 
materials on the world market is the reflection of the current situation where there is no balance of supply and demand: producers are not offering enough beans to consumers due to the deterioration of the crop in the main producing countries - Ghana and Ivory Coast. According to the International Cocoa Organization, in the 2019 season, there was a shortage in the market, namely, the global demand for beans exceeded the supply by 21 thousand tons, as a result of which raw material prices increased. The adoption of State support measures for farmers in Ghana and Ivory Coast to combat poverty also contributed to the increase in prices. According to the World Bank, $80 \%$ of cocoa producers (4 million people) earn less than 3 US dollars per day. The authorities of the countries introduced a surcharge for producing farms in the amount of 400 US dollars per 1 ton above the exchange price [6].

Basing on the exchange level, the export prices for beans in African countries are formed. Cocoa trading on the stock exchange takes place with the help of futures, thanks to which producers and exporters are insured against possible future price falls, and importers - against possible future price increase, while traders take profits at the moment. Cocoa futures on the London Stock Exchange are used as a global benchmark for the formation of the export price of raw materials. The cocoa market can be described as "efficient" because it operates with perfect competition, and the price is "fair" and is determined as a result of large volumes of trading, which makes it extremely difficult for any trader to influence the cost of forward deliveries.

The mechanism for adjusting the futures price is the correction differential, which is individual for each exporting country. It is used to generate the contract price. The differential includes production and administrative costs, logistics costs, the profit of all participants in the export supply, as well as the safety factor of doing business with the exporting country. This mechanism can be positive, that is, added to the average price of the exchange, or negative - subtracted from the exchange price. A negative differential is found in Africa if deliveries from a particular country are risky and involve deceiving buyers in terms of the quality of the goods sent to them or not delivering the goods against the money already received for it.

There are many factors that affect the exchange pricing of the global cocoa bean market, including its derivatives.

The main Top-9 factors:

1) Geographically concentrated production

Two-thirds of the world's bean production is in West Africa, where the largest producers are Ghana and Ivory Coast. This means that the price of raw materials is subject to supply disruptions and delays caused by the problems of African countries.

\section{2) Weather}

A moderate combination of rain and sunlight is necessary for the proper maturation of the chocolate tree fruit. Climate disruption at any stage of the growth process can have a direct impact on the crop. For example, drought contributes to the appearance of shriveled or rotten fruit, so African farmers watch daily for winds from the Sahara Desert, which bring dry weather and coolness from December to February. Strong dusty winds, known as Harmattan, dry fruits and damage crops, leading to a shortage of high-quality raw materials, and therefore to higher prices for limited volumes.

3) Diseases

The disease reduces the performance due to the decrease in the yield of cocoa plantations. The most devastating disease affecting the fruit, known as "Black Stick", led to the loss of almost half a million tons of beans in 2010. The Ebola outbreak in 2014 forced farmers and their families to leave cocoa plantations in Sierra Leone, and international traders, in turn, refused to trade beans from producing African countries during the 
pandemic, which contributed to the decline of the cocoa market as a whole due to reduced supply.

4) Farms

The price that a farmer receives for beans is set by the industry regulator. If manufacturers ' incomes are reduced due to the decline in the market value of cocoa on the African continent caused by government regulation of domestic prices, they invest less in new chocolate trees and reduce the consumption of fertilizers and other important resources that ensure high quality of cocoa beans. This leads to an increase in the quality of goods below average, and, consequently, to a decrease in the export supply of beans in the short term.

5) Warehouse stock

The high level of cocoa stocks provokes a decrease in demand for them. Moreover, beans are perishable raw materials, and depending on storage conditions, their quality can quickly deteriorate, thereby African farmers can lose a significant part of their revenue. In such circumstances, the manufacturers sell the stocks at the low prices which leads to the collapse of the market.

6) Geopolitics

African cocoa producers are operating in an environment of geopolitical uncertainty. Like many countries that rely on commodities as the bulk of their export earnings, Ivory Coast is plagued by corruption and power struggles. Most of the continent's economic booms, associated with the change of power and the election of a new president, are followed by popular unrest, which leads to industrial strikes and downtime of bean farms and provokes a shortage of raw materials.

7) Infrastructure

The largest cocoa producers do not have a developed infrastructure, which contributes to an artificial increase in the final prices of raw materials. In the transport sector, there are problems with crumbling roads that are not suitable for transporting goods in the rain. Therefore, logistics to the ports becomes more expensive, and additional costs are shifted to the price of the goods. In the freight forwarding sector, there are many problems with the certification of goods, the issuance of permits and export declarations, which are caused by bureaucracy and the non-compliance of the legislation of African producing countries with the norms of international transport and trade. For example, the return to the importer of a security customs payment for the import of beans into the country of destination occurs only if a full set of documents for the arrived cargo is provided, some of which are not issued by African exporters due to the lack of appropriate certification institutions in the country of departure. In case of non-return of security customs payment, the importer is forced to bear losses at his own expense, then raising the prices of the imported goods on the domestic market in order to recoup the costs incurred.

8) Consumer preferences

The global trend towards dark chocolate, especially as a potential health benefit, is helping to drive demand for beans. Dark chocolate requires a higher cocoa content than milk chocolate. Meanwhile, chocolate is becoming increasingly available in African countries themselves, increasing the demand for raw materials. In such conditions, traders tend to reduce the purchase prices of beans from farms when contracting large volumes for the conclusion of long-term uninterrupted delivery, which in turn is beneficial for manufacturers in the matter of monthly shipments and receiving stable payments for the goods.

9) Exchange rate Fluctuations

Cocoa beans are priced in pounds sterling, trading on London. Since cocoa consumption is concentrated in continental Europe, and most of the cocoa processing industry is based in 
the Netherlands, the fall in the value of the pound against the euro increases the demand for beans, as they become relatively cheaper to import for further processing.

Thus, the deviation of any of the above factors from the norm has a significant impact on the pricing of the world market of cocoa beans and their cross-country commodity flow, in particular exports.

The world's largest cocoa exporters are Ivory Coast, Ghana, Ecuador, Belgium, the Netherlands, and Malaysia (Fig. 1).

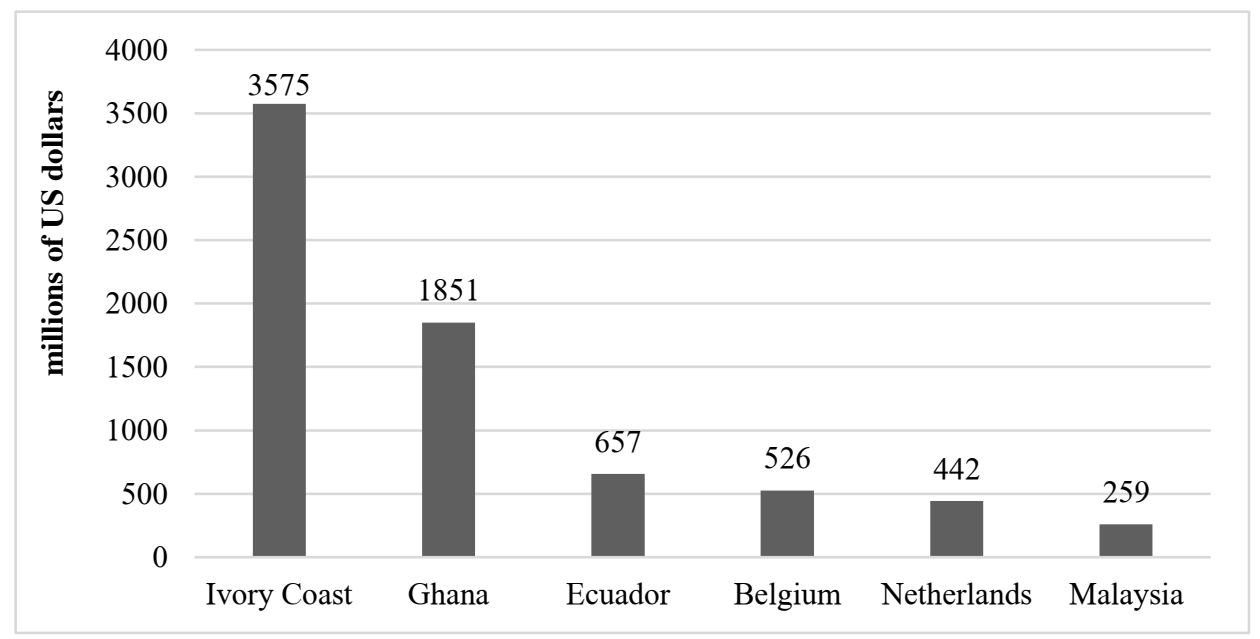

Fig. 1. The world's largest cocoa bean exporters in 2019.

In 2019, the export value of cocoa beans from Ivory Coast amounted to 3,575 billion US dollars, namely $44,39 \%$ of global market share, from Ghana - 1,851 billion US dollars $-22,99 \%$ of global market share, from Ecuador -657 million US dollars $-8.16 \%$ of global market share, from Belgium - 526 million US dollars $-6.54 \%$ of global market share, the Netherlands - 442 million US dollars $-5,49 \%$ of global market share, from Malaysia 259 million US dollars $-3.22 \%$ of global market share.

In Ivory Coast, Ghana and Ecuador, beans are the main export commodity, the supply of which is regulated at the state level by the Governments of these countries.

In Ivory Coast, since the last reforms in 2011, the price of beans for farmers is fixed by the Coffee and Cocoa Council (CCC) through the Expected Sales Program at $60 \%$ of the value at which the CCC can carry out its forward transactions. In theory, a price fix for a year is a guarantee for producers, regardless of the market movement during the year. Moreover, to ensure price stabilization for farmers, the CCC has created The Reserve Fund to protect against a possible fall in the cost of cocoa in the future. However, in 2016, there was a significant drop in world bean prices, caused by an $18 \%$ increase in cocoa production, including in Ivory Coast [5]. Although the Government sold most of the expected crop ahead to national traders, they, in turn, refused to buy cocoa from farmers at a fixed contract price and defaulted on the concluded forward deliveries. The Reserve Fund was not able to guarantee a stable income for farmers and the Ivorian Government was forced to reduce their prices by $36 \%$, which raised many questions about the sustainability of such an institutional price control mechanism. With such a monopoly position of the state in export sales, African producers annually receive consistently lower revenue than under market liberalization.

In Ghana, the price of cocoa is fixed annually by the Producer Price Review Committee (PPRC) at the beginning of the harvest season in October and remains unchanged for twelve months. The PPRC has set the farmer's price at $75 \%$ of the FOB price. The 
remaining $25 \%$ of the export value is used to cover such cost items as financing the next crop, storage, disinfection, sorting, certification, inspection, logistics, as well as to generate Government revenue. Thus, part of the income from the sale of cocoa is reinvested in this industry. Under this pricing condition, farmers do not have the opportunity to independently differentiate the cost of goods by quality and there is a lack of transparency in the decision-making process. Nevertheless, producers in Ghana receive institutional support. So, there are premium surcharges to the export price from the state as a fight against poverty in the country. Fixed prices can be beneficial to Ghanaian farmers when global market prices fall during the season. On the other hand, in a bull market, cocoa producers do not benefit from higher prices, as traders open deals to buy beans from Ghana when the asset price is low and close them when it is high.

After the harvest, the cocoa beans are dried, fermented and exported from Ivory Coast, Ghana and Ecuador to the Netherlands and Belgium for further resale in Europe, as well as to the United States for processing. Thus, the world's second largest cocoa port is located in Antwerp (Belgium), from where the commodity flow is then distributed throughout Europe. The main importers of beans from Belgium are Austria, Germany and France. The fifth largest exporter of beans in 2019 was the Netherlands. Amsterdam is home to the largest cocoa port in the world. The Netherlands processes cocoa beans into such derivatives as cocoa powder and cocoa butter, and then distributes them to markets in Europe and Russia.

The sixth largest exporter of beans in the world, and the leading processor of cocoa in Asia and Oceania, is Malaysia. Because the country's yields are insufficient for its large processing sector, Malaysia imports most of its cocoa beans from Papua New Guinea. After processing, the country exports bean derivatives: cocoa powder and cocoa butter.

So, in 2019, the total export value of cocoa beans of the five main exporters of the world amounted to 7.310 billion US dollars, which was equal to $90.79 \%$ of the global market value of this product.

Since most of the production demand for cocoa beans comes from processing enterprises that use raw materials to create the derivatives that underlie chocolate, namely, powder and butter, it is necessary to develop an integrated price model of the cocoa industry economy, including all its derivatives, to optimize the trade and production process.

The model can be represented by a diagram describing individual aspects of the functioning of each private business process of a given commodity market. (Fig. 2). 




Fig. 2. Schematic representation of the integrated cocoa market model.

This theoretical model is useful when complex market relations between a number of interrelated variables are interpreted in practice by an erroneous pattern. It can serve as a guide for applied econometric studies of specific aspects of the cocoa industry economy.

The main postulates of the model:

- Demand for cocoa powder stocks ultimately plays a key role in shaping the price of the powder and depends on the balance between storage costs and expected price increases.

- Government regulation has an impact on the demand for grinding cocoa and butter.

- To simplify the factors of dependence of the final demand for each bean derivative as much as possible, we assume that the demand for chocolate depends only on the average income per capita.

- The demand for cocoa butter for the chocolate industry depends in part on the prices of its substitutes.

Macroeconomic indicators in this model act as endogenous and exogenous variables. The endogenous variables are determined by the model itself in accordance with the relationships between the cocoa bean derivatives contained in it. Exogenous variables are other variables that are not explained by the model and are accepted as data.

List of endogenous variables:: 
1. $D_{\text {choc, }}$ Dliqtot, $D_{\text {coc, }}$ D but, $D_{\text {pow: }}$ the volume of demand, respectively, for chocolate, grinding cocoa, beans, butter and powder

2. $\mathrm{S}_{\mathrm{choc}}, \mathrm{S}_{\text {liq, }}, \mathrm{S}_{\mathrm{coc}}, \mathrm{S}_{\mathrm{but}}, \mathrm{S}_{\mathrm{pow}}$ : the volume of the supply, respectively, chocolate, grinding cocoa, beans, butter and powder

3. $P_{\text {choc }}, P_{\text {liq, }}, P_{\text {coc }}, P_{\text {but }}, P_{\text {pow }}$ : the market price, respectively, for chocolate, grinding cocoa, beans, butter and powder

4. $\mathrm{X}_{\mathrm{coc}}, \mathrm{X}_{\text {pow }}$ : actual year-end stocks of beans and powder

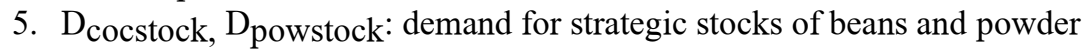

6. Spressbut: offer of pressed cocoa butter

7. Dliqchoc: demand for grinding cocoa used directly in the production of chocolate

8. Dliqbut: demand for grinding cocoa used directly for processing into cocoa butter

List of exogenous variables:

1. Y: real income per capita in the consumer country

2. S Socnorm: standardized production of cocoa beans (in each country) or production capacity, depending on the size of the plantation area and its structure

3. P cocexp: expected price of beans

4. P Powexp: expected price of powder

5. R: the costs of storing

6. $\mathrm{G}_{1}$ : factors of state regulation that determine the minimum allowable amount of grinding cocoa and cocoa butter in chocolate

7. $\mathrm{G}_{2}$ : factors of state regulation that determine the minimum permissible amount of use of substitutes of butter in chocolate instead of butter

8. Pbutsubst: price of butter substitutes

Considering all the variables, we can conclude that the grinding cocoa market is completely autonomous, which directly depends on the demand for chocolate and on the prices of cocoa beans. The butter and powder markets, on the other hand, have many dependencies on both grinding cocoa and each other. These dependencies allow us to conduct a constructive analysis of the market features and make behavioral linear equations of the industry sectors as follows:

$$
\begin{aligned}
& \mathrm{S}_{\mathrm{coc}}=\mathrm{c}_{\mathrm{O}}+\mathrm{c}_{1} \mathrm{~S}_{\text {cocnorm }}+\mathrm{c}_{2} \mathrm{P}_{\mathrm{coc}} \text {. } \\
& D_{\text {choc }}=a_{0}+a_{1} Y \\
& \text { Dliqchoc }=b_{0}+b_{1} D_{\text {choc }}-b_{2} P_{\text {liq }}+b_{3} G_{1} \text {. } \\
& \mathrm{D}_{\text {liqbut }}=\mathrm{yD} \text { but } \\
& D_{\text {liqtot }}=\mathrm{D}_{\text {liqchoc }}+\mathrm{D}_{\text {liqbut }} \\
& \mathrm{S}_{\text {liq }}=\mathrm{wS}_{\mathrm{coc}} \\
& \mathrm{P}_{\text {liq }}=\mathrm{d}_{\mathrm{O}}+\mathrm{d}_{1} \mathrm{P}_{\mathrm{coc}}-\mathrm{d}_{2}\left(\mathrm{~S}_{\text {liq }}-\mathrm{D}_{\text {liqtot }}\right) \\
& \mathrm{D}_{\mathrm{coc}}=\mathrm{zD} \text { liqtot }+\mathrm{D}_{\text {cocstock }} \\
& \mathrm{X}_{\mathrm{coc}}=\mathrm{S}_{\mathrm{coc}}-\mathrm{D}_{\mathrm{coc}} \\
& \mathrm{D}_{\text {cocstock }}=\mathrm{h}_{\mathrm{O}}+\mathrm{h}_{1}\left(\mathrm{P}_{\text {cocexp }}-\mathrm{P}_{\text {coc }}\right)-\mathrm{h}_{2} \mathrm{R} \\
& \mathrm{P}_{\mathrm{coc}}=\mathrm{e}_{\mathrm{O}}-\mathrm{e}_{1} \mathrm{X}_{\mathrm{coc}}
\end{aligned}
$$




$$
\begin{gathered}
\mathrm{D}_{\text {but }}=\mathrm{k}_{\mathrm{o}}+\mathrm{k}_{1} \mathrm{D}_{\text {choc }}-\mathrm{k}_{2} \mathrm{P}_{\text {but }}+\mathrm{k}_{3} \mathrm{G}_{2}+\mathrm{k}_{4} \mathrm{P}_{\text {butsubst }} \\
\mathrm{S}_{\text {pressbut }}=\mathrm{g}_{\mathrm{o}}+\mathrm{g}_{1}\left(\mathrm{~S}_{\text {liq }}-\mathrm{D}_{\text {liqchoc }}\right)+\mathrm{g}_{2} \mathrm{P}_{\text {but }} \\
\mathrm{P}_{\text {but }}=\mathrm{n}_{\mathrm{O}}+\mathrm{n}_{1} \mathrm{P}_{\text {liq }}-\mathrm{n}_{2}\left(\mathrm{~S}_{\text {pressbut }}-\mathrm{D}_{\text {but }}\right)
\end{gathered}
$$

In particular, the powder market model is described as follows:

$$
\begin{gathered}
\mathrm{S}_{\text {pow }}=\mathrm{q}_{\mathrm{o}}+\mathrm{q}_{1} \mathrm{~S}_{\text {pressbut }}+\mathrm{q}_{2} \mathrm{P}_{\text {pow }} \\
\mathrm{D}_{\text {pow }}=\mathrm{r}_{\mathrm{O}}+\mathrm{r}_{1} \mathrm{Y}-\mathrm{r}_{2} \mathrm{P}_{\text {pow }}+\mathrm{r}_{3} \mathrm{D}_{\text {powstock }} \\
\mathrm{D}_{\text {powstock }}=\mathrm{v}_{\mathrm{O}}+\mathrm{v}_{1}\left(\mathrm{P}_{\text {powexp }}-\mathrm{P}_{\text {pow }}\right)-\mathrm{v}_{2} \mathrm{R} \\
\mathrm{X}_{\text {pow }}=\mathrm{S}_{\text {pow }}-\mathrm{D}_{\text {pow }} \\
\text { Ppow }=\mathrm{so}+\mathrm{s} 1 \text { Pliq }-\mathrm{s} 2 \mathrm{Xpow}
\end{gathered}
$$

Thus, all the main indicators of supply and demand in the cocoa market and their interaction with various economic factors were integrated into an artificial theoretical model that describes the pricing of the single world cocoa market through its raw materials (beans) and commodity (powder and butter) industries. It can be used for predictive scenarios of market development, including to assess how the wider use of butter may affect the price of powder.

From the point of view of government regulation, price interventions prove that the market is a system that generally follows the economic principles of global supply and demand. It is impossible to interfere in one aspect of pricing without causing consequences in others. State monopolization of export volumes should not have a negative impact on the main market participants, who are the first in the supply chain - farmers, whose profitable activities directly depend on the balance of supply and demand. Developing the right pricing policy is a key task for African Governments in the context of the bean exchange trade.

\section{References}

1. International Cocoa Organization (ICCO), Quarterly Bulletin of Cocoa Statistics (2020)

2. L.W. Bensdorp, Cocoa powder: niche marketing. International Cocoa Organization, Eight meeting of the Advisory Group on the World Cocoa Economy (1995)

3. K. Kunanbaeva, S. Rahimova, A. Titkov, L. Goncharenko, E3S Web of Conferences 164 (2020)

4. R. Bymolt, A. Laven, M. Tyszler, Demystifying the cocoa sector in Ghana and Côte d'Ivoire (Cocoa marketing and prices, The Royal Tropical Institute, 2018)

5. Rambler news, As a record increase in prices for cocoa beans can affect the confectionery industry in Russia (2020)

6. L. Akhmetshina, A. Mussina, S. Izmaylova, IOP Conf. Series: Earth and Environmental Science 403, 012168 (2019) doi:10.1088/1755-1315/403/1/012168

7. L. Akhmetshina, A. Sergeev, A. Mottaeva, E3S Web of Conferences 91, 06008 (2019)

8. S. Rakhimova, K. Kunanbayeva, L. Goncharenko, A. Pigurin, E3S Web of Conferences 110, 02154 (2019) 